\section{Haemophilus influenzae type b meningitis resistant to ampicillin and chloramphenicol}

Sir,

Guiscafre et al have reported two cases of meningitis due to Haemophilus influenzae type b resistant to ampicillin and chloramphenicol. ${ }^{\prime}$ In their report they say 'since 1980 eight cases of meningitis. . . have been reported'. This is not true. In previous reports we have drawn attention to the explosive increase of multiply resistant strains of $H$. influenzae type b causing invasive and non-invasive infections in Spain. ${ }^{2}{ }^{3}$ From January 1981 to December 1984 we have seen over 364 consecutive cases of culture proved bacterial meningitis, 35 of which $(9.6 \%)$ were caused by $H$. influenzae type b. In 20 cases $(57 \%)$ strains were found to be resistant to ampicillin and chloramphenicol.

As this problem has also been described in other parts of Spain we are led to the conclusion that in our country resistance of $H$. influenzae $b$ to ampicillin and chloramphenicol could be endemic. Uncontrolled and widespread use of antibiotics in Spain over many years played a role in the emergence of these multiply resistant strains.

We cannot use ampicillin and chloramphenicol as initial treatment of meningitis caused by $H$. influenzae $b$ and we are currently using cefotaxime as the treatment of choice until susceptibility tests become available.

The report from Mexico, like others, remind us of the possibility of emergence of strains resistant to both antibiotics in every country.

\section{J M Gairi, J Campos, and S Garcia-Tornel San Juan de Dios Children's Hospital.} Barcelona, Spain

\footnotetext{
References

I Guiscafre H. Solorzano F, Delgado O. Muñoz. O. Hacmophilus influenzac type b meningitis resistant to ampicillin and chloramphenicol. Arch Dis Child 1986:61:691-2.

2 Campos J. Garcia-Tornel S, Gairi JM. Invasive infections caused by multiply resistant Hacmophilus influenzac type b. $J$ Pediatr 1984:104:162-3.

3 Campos J, Garcia-Tornel S, Sanfeliu I. Susceptibility studies of multiply resistant Haemophilus influenzae isolated from pediatric pationts and contacts. Antimicrob Agents Chemother 1984:25:706-9.
}

\section{High plasma urea concentration in babies with lamellar ichthyosis}

\section{Sir,}

The interesting observation of Beverley and Wheeler about raised plasma urea concentration after cutaneous application of Calmurid (10\% urea and 5\% lactic acid) in collodion babies or in babies with lamellar ichthyosis was attributed to increased urea absorption through the skin.' This explanation seems logical. There are two additional factors that may contribute, however, to the rise in plasma urea in these patients: (a) the application of a hygroscopic substance like urea can increase the hydration of the skin² but may decrease the water contents of other tissues, and (b) babies with lamellar ichthyosis have a tendency towards dehydration caused by increased loss of water through the affected skin. My colleagues and I reported several babies with lamellar ichthyosis who developed hypernatraemic dehydration due to excessive loss of water through the skin. ${ }^{3}$ They were not treated with urea cream but developed raised serum urea on several occasions in association with hypernatraemic dehydration, as can be seen from the examples in the Table.

Table Urea concentrations in three cases of lamellar ichthyosis who developed hypernatraemic dehydration

\begin{tabular}{|c|c|c|c|c|c|c|}
\hline \multirow{2}{*}{$\begin{array}{l}\text { Case } \\
\text { No }\end{array}$} & \multirow{2}{*}{$\begin{array}{l}\text { Age } \\
\text { (days) }\end{array}$} & \multicolumn{2}{|c|}{ Weight loss } & \multirow{2}{*}{$\begin{array}{l}\text { Plasma } \\
\text { - urea } \\
\text { (mmol/l) }\end{array}$} & \multirow{2}{*}{$\begin{array}{l}\text { Plasma } \\
\text { sodium } \\
(m E q / l)\end{array}$} & \multirow{2}{*}{$\begin{array}{l}\text { Plasma } \\
\text { chloride } \\
(m E q / l)\end{array}$} \\
\hline & & $(g)$ & $\begin{array}{l}(\% \text { Of body } \\
\text { weight })\end{array}$ & & & \\
\hline 1 & 3 & 490 & 11 & $10 \cdot 0$ & 159 & 118 \\
\hline 2 & 42 & 160 & 7 & $9 \cdot 6$ & 165 & 120 \\
\hline \multirow[t]{2}{*}{3} & 91 & 165 & 7 & $9 \cdot 6$ & 158 & 126 \\
\hline & 334 & 140 & 5 & 29.9 & 179 & 151 \\
\hline
\end{tabular}

The state of hydration of babies with lamellar ichthyosis can be difficult to evaluate as the skin turgor is not a reliable sign of hydration. The amount of water loss through the skin in lamellar ichthyosis is variable and probably depends on the condition of the skin; shedding of the scales, with exposure of great areas of erythematous skin can increase the insensible water loss, although aesthetically the skin appears improved. Thus dehydration can be a relatively common cause of rises in plasma urea concentration in babies with lamellar ichthyosis.

$$
\begin{array}{r}
\text { B Z GARTY } \\
\text { The Children's Hospital of Philadelphia, } \\
\text { Philadelphia, } \\
\text { United States of America }
\end{array}
$$

Drs Beverley and Wheeler comment:

We read with interest the comments of Dr Garty and agree with him that other factors may have contributed to the raised plasma urea in our patients, particularly in case 1 who had lamellar ichthyosis. We were able, however, to observe case 2 (whose underlying skin was normal) more closely. She had normal plasma creatinine concentrations at the time of the raised plasma urea concentration (as shown in the Figure of our paper ${ }^{1}$ ), her weight never fell more than expected for a newborn infant, the plasma urea fell on stopping treatment with Calmurid, and throughout she maintained a good urine output. These factors suggested to us that the primary cause of the raised urea was transdermal absorption of urea rather than dehydration as suggested by Dr Garty. Because of our experience with case 1 we felt it to be inappropriate to challenge case 2 with further treatment with Calmurid to determine whether the plasma urea would rise again. The patients that Dr Garty describe are of interest; again making the point that skin, in particular abnormal skin, is not an impermeable barrier, in his cases there was excessive 